Remote sensing

\section{British images up for sale}

A $£ 14$ MILLION programme to promote development and commercial exploitation of remote sensing in Britain was announced last week by $\mathrm{Mr}$ Kenneth Baker, Minister for Information Technology. The immediate aim is to seek "maximum possible benefits" from the European Space Agency (ESA)'s Earth Resources Satellite (ERS1), due for launch in 1987.

A new coordinating body, the National Remote Sensing Programme Board, will run the programme. The board, which includes representatives from government departments, research councils and industrial companies, will advise on the resources needed and will promote applications of remote sensing. As well as overseeing the ERS1 programme in Britain, it will supervise the National Remote Sensing Centre at Farnborough, which processes data obtained through ESA's "Earthnet" scheme. Mr Baker said that this agreement will encourage private companies to exploit added-value services as soon as possible.

Behind the government's enthusiasm there is concern that industry has been slow to make use of remote sensing data. Opinion is united on the aesthetic value of remotely-sensed images, but US experience is not encouraging. When the National Oceanic and Atmospheric Administration took over the Landsat programme on 31 January this year, only one serious customer was found for the data and then only after especially favourable terms (which included government purchase guarantees) were offered (see Nature 10 March, p.96). The British Government has, however, declined to follow the French course of helping to set up an independent company to market remote sensing data.

The $£ 14$ million set aside for the new scheme is on the low side of the recommendations made to $\mathrm{Mr}$ Baker a year ago by a specially convened "task force". The government seems to have recognized the need for development in ground computing techniques to put data into a usable form, but some scientists feel there should be more support for the development of more advanced sensing instruments.

ERS1 will be a partly experimental oceanographic and coastal monitoring satellite along the lines of Seasat. The British contribution to the satellite, which will be launched by Ariane 2 or 3, will be worth $£ 10$ million per annum by $1984-85$. The main payload will consist of a radar altimeter, which can measure the satellite's height above the waves with a precision greater than $10 \mathrm{~cm}$, and an active microwave instrument combining the functions of a wind and wave scatterometer and a synthetic aperture radar. This instrument will measure wind and wave directions in all weather conditions. An additional

\section{British AIDS}

experiment, the Along Track Scanning Radiometer, has been provided by the UK Science and Engineering Research Council out of its own funds.

Apart from their academic interest, data from ERS1 will be used in forecasting weather and sea conditions, including seaice, and for advisory services to offshore

industries. Possible future applications for remote sensing include fisheries management and monitoring marine pollution. A land applications satellite to follow ERS1 is planned, although few details have been decided. In commercial terms, land data are likely to be more profitable in the long run, with obvious applications in mineral prospecting and in agriculture. But experience with rapidturnaround ocean data may make it easier to persuade industry to take notice.

Tim Beardsley

\title{
Whose blood can now be safe?
}

FEARS that the spread of acquired immune deficiency syndrome (AIDS) in Britian may be hastened by the use of blood products imported from the United States have prompted a trades union leader to attack the government for allegedly failing to provide adequate support for the Blood Products Laboratory (BPL) at Elstree, in Hertfordshire.

The worries concern supplies of factor VIII, the clotting agent used to treat haemophilia. There are about 4,000 haemophiliacs in Britain, and 60 per cent of the factor VIII they use is imported from the United States, where (in contrast to Britain) donors are frequently paid to give blood. An official of ASTMS, the union representing technicians at BPL, said last week "It is common knowledge that many blood donors in the United States are on Skid Row and may be carrying AIDS". The disease is thought to have a long latency period.

No causative agent for AIDS has been identified, but there is evidence suggesting that AIDS is transmitted in blood products, (see Nature 28 April, p.749). There are 11 haemophiliacs among the thousand or so AIDS victims in the United States - more than would be expected by chance - and, along with male homosexuals, intravenous drug users are also known to be especially at risk. A recent issue of The Lancet records the first three reported cases of AIDS from Spain, all of whom are haemophiliacs. There are now 14 confirmed cases of AIDS in Britain, and one recent suspected case is in a male haemophiliac who is neither a homosexual nor a drug user.

A second factory now under construction at Elstree should make Britain self-sufficient in factor VIII by $1985-86$, but until then the country is dependent on imports. Mr Clive Jenkins, general secretary of ASTMS, claimed last week that managers at BPL have been told to cut their budgets by 10 per cent. The Department of Health has strongly denied Jenkins" claims, which it calls "entirely untrue". The department says that, in line with other public services, the laboratory's budget has been increased by 5 per cent. But Mr Norman Pettit, assistant to the director at BPL, confirmed last week that 10 per cent cuts had been ordered. It is not clear whether cash limits will delay the plant.

Most factor VIII is now extracted from pooled donations from 4-5,000 people. This makes the potential risk much greater than with ordinary blood transfusions, which typically contain blood from only three or four donors.

Dr Harold Gunson, who advises the British Department of Health on blood products, said that the situation was being kept under review, but that in his opinion there was insufficient evidence to justify reducing US factor VIII imports immediately. There is growing pressure on the National Blood Transfusion Service to exclude homosexuals from its pool of donors, but Dr Gunson says "We just can't do that". It is thought that asking direct questions about donors' sexual proclivities would be unacceptable in Britain - and might not yield the truth.

All such problems would vanish were it possible to produce factor VIII by means of recombinant DNA technology. That could become possible within 18 months (although not necessarily as a commercial venture) through the joint efforts of Dr Edward Tuddenham and his colleagues at the Royal Free Hospital in London, the British blood products company of Speywood Laboratories and Genentech, the Californian biotechnology company. Speywood carries out the first steps in purification of factor VIIIC (the subcomponent of factor VIII that is deficient in haemophilia) which Dr Tuddenham purifies further. Genentech is trying to clone the factor VIIIC gene and to express it in microorganisms. Rivalry comes from Biogen with Kabivitrum and from the Scripps Clinic and Research Foundation with Johnson and Johnson.

Speywood's backers, the British Technology Group and Prutec, have recently insisted that the company should cut back on some of its research expense in universities. Dr Tuddenham's work has apparently not suffered as a result but research parallel to that of Genentech's on factor VIIIC gene cloning under Professor George Brownlee at the Sir William Dunn School of Pathology in Oxford is being delayed for lack of full support from Speywood. 